\title{
THE IMPACT OF EXCESS RAINFALL ON THE MAXIMUM FLOW RATE IN THE UPPER AND MIDDLE BASIN OF PRAHOVA RIVER
}

\author{
A.-V. TUDORACHE ${ }^{1,2}$
}

\begin{abstract}
The impact of excess rainfall on the maximum flow rate in the upper and middle basin of Prahova River. The present paper analyzes the impact of excess rainfall on the maximum flow rate in the upper and middle basin of Prahova River. In the last centuries, the upper and middle basin of the Prahova River has been increasingly affected by floods, which have had importand social and economic consequences, for this reason, this study is focused on the impact of the excess rainfall over the maximum flow rate and also the spatial and temporal variability of it, centered in the 19932013 period. The monthly and annual maximum flow data series from Bușteni and Câmpina hydrometic stations were capitalized through statistical analyzes. Maximum flows were reported at the tresholds values according to DEFENCE LEVELS. The purpose of the paper is to highlight how the maximum flow varies during the analysed period, to mark the floods that have taken place in this area, their impact on society and the environmnet, and also methods to combat negative effects.
\end{abstract}

Keywords: excess precipitations, maximum flow, flash flood, hydrometric stations

\section{INTRODUCTION}

Climate change and global warming are complex topics of great relevance, both at national and international level, scientific research about this issue are extremely important and necessary in the current climate context.

Climate variability, caused by hot air advections of different origins, is also manifested in the Prahova River basin, with negative economic and social consequences.

The maximum flow is mainly determined due to the abundant precipitation and snow melting water. Among the determining factors can be mentioned: the climate, the surface and shape of the hydrographic basin, the soil, the use / coverage of the land, etc. (Pisota, I., Zaharia, L., Diaconu, D., 2005).

Prahova River is characterized by a hydrological regime caused by rain and snow (Musy, 2005), with low water in January and high waters at the end of spring.

\footnotetext{
${ }^{1}$ Faculty of Geography, University of Bucharest, 1 Nicolae Bălcescu Blvd., Sector 1, 010041, Bucharest, Romania, e-mail: tudoracheav@gmail.com

${ }^{2}$ National Institute of Hydrology and Water Management, 97 E Bucuresti-Ploiești St., Sector 1, 013686, Bucharest, Romania.
} 


\section{GENERAL GEOGRAPHICAL CHARACTERISTICS OF THE PRAHOVA RIVER BASIN}

The Prahova River is the most important component of the Ialomița hydrographic system. It springs from the northern slopes of Susai Mountain, at an altitude of $1100 \mathrm{~m}$, and flows in the Ialomita River, at Adâncata. The Prahova River gathers its tributaries from the Bucegi-Gârbova-Ciucaș Mountains and the Curvature Subcarpathians sector (Nedelcu, A., 2010).

The middle and upper basin of the Prahova River overlaps over two large relief steps, considered to be an altohton river. The mountainous sector corresponds to the Southern Carpathians (Bucegi Mountains, Gurguiatu Mountains, Predeal Mountains) and the Carpathian Mountains (Gârbova Mountains), and the Subcarpathian sector corresponds to the Curvature Subcarpathians (Fig.1).

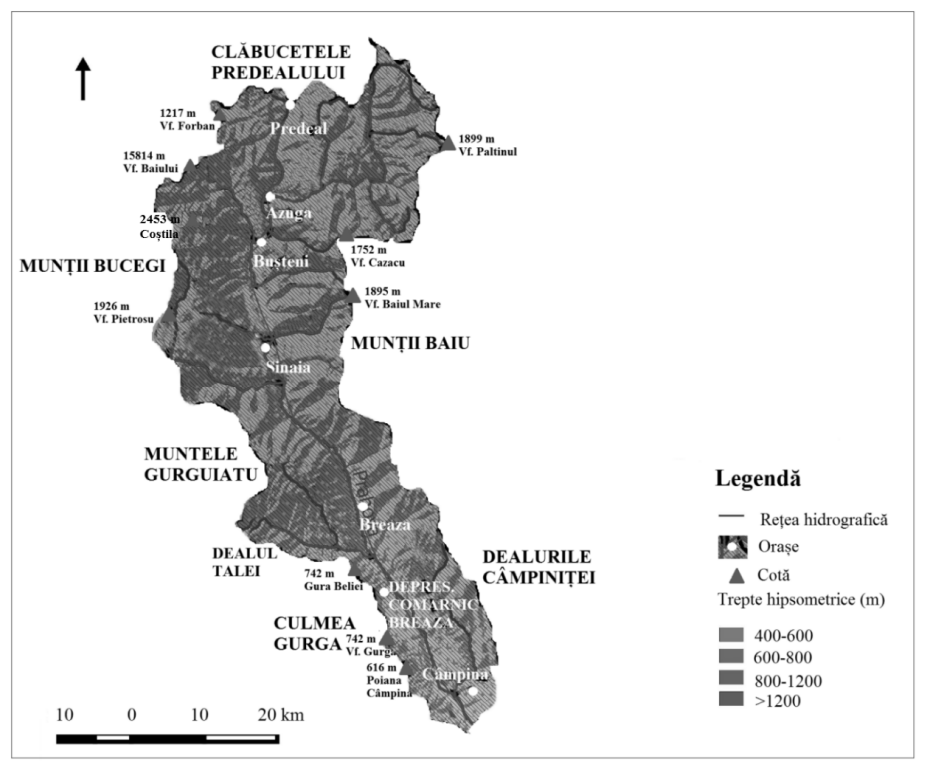

Fig.1. Hypsometric map and the main relief subunits in the Prahova catchment area, upstream of Câmpina

This development influenced the evolution of the Prahova hydrographical basin by giving it specific morphological and morphometric features (Roșu, Al., 1973). The relief, due to its geomorphometric features (altitude, relief, relief fragmentation density etc.), has a major influence on the formation of water resources and on the reception, accumulation and control conditions of rainfall and snow melting.

The surface of the basin, upstream of Câmpina, is $429 \mathrm{~km}^{2}$, being considered a basin with a small extension. The length of the river from the spring to Câmpina is $75 \mathrm{~km}$. 
From the spring to the Câmpina hydrometric station, Prahova receives the following tributaries: on the left: Valea Turcului, Limbășel, Azuga, Valea Fetei, Zamora, Valea Rea, Câmpea and on the right: Valea Cerbului, Valea Albă, Izvorul Dorului, Valea Beliei and Talea (Fig. 2).

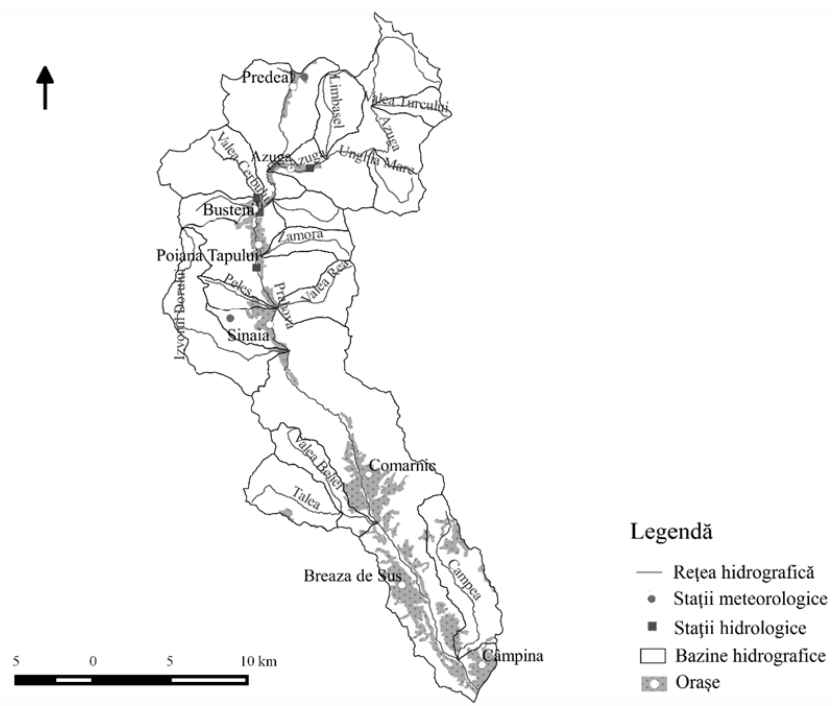

Fig. 2. Prahova River basin and hydrographic network, upstream of Câmpina

In the following pictures (Photo 1 and Photo 2.) the Prahova River is presented in Buşteni and Câmpina area.

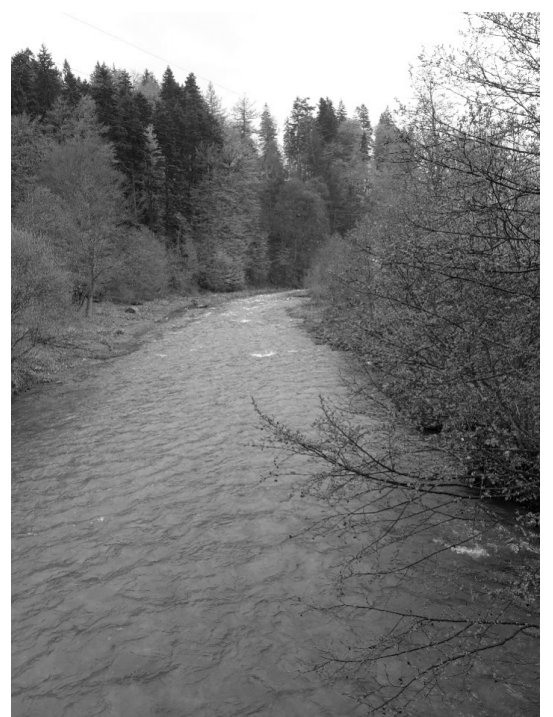

Photo 1. Prahova River at Bușteni

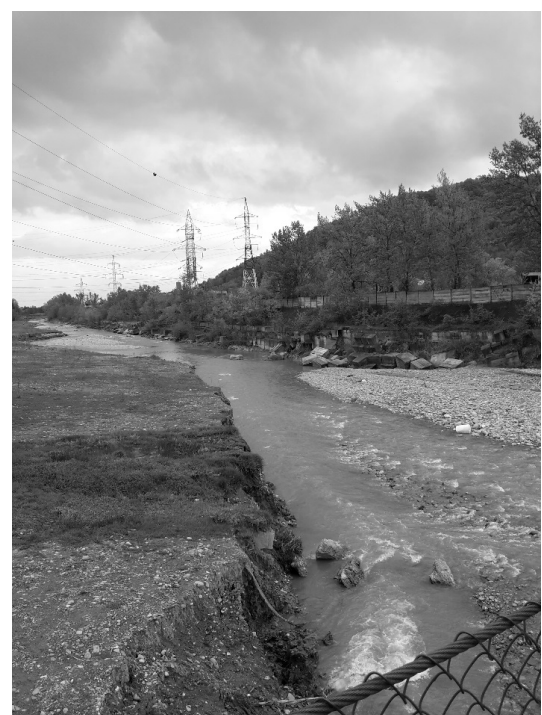

Photo 2. Prahova River at Câmpina 


\section{DATA AND METHODS}

In order to achieve the study we used the maximum monthly flows recorded at two hydrometric stations within the Prahova basin, namely Bușteni and Câmpina, for the period 1993-2013. These have been reported at the threshold values corresponding to DEFENSE LEVELS, with increased attention on FLOOD AND DANGER LAVELS. The current limnimetric key (Table 1) was used to determine the corresponding flow rates.

Table 1. Morphometric and hydrological data on the maximum flow of Prahova river at Buşteni and Câmpina hydrometric stations

\begin{tabular}{|c|c|c|c|c|c|c|c|c|c|c|c|c|c|c|c|c|}
\hline \multirow{2}{*}{$\stackrel{\grave{D}}{\underline{x}}$} & \multirow{2}{*}{$\stackrel{\dot{P}}{\dot{x}}$} & \multirow{2}{*}{ 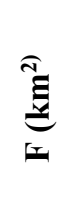 } & \multirow{2}{*}{ 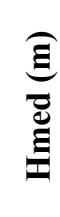 } & \multirow{2}{*}{ 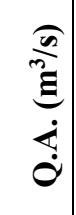 } & \multirow{2}{*}{$\begin{array}{c}\frac{a}{\sigma} \\
\stackrel{a}{a} \\
\dot{\dot{\sigma}}\end{array}$} & \multirow{2}{*}{ 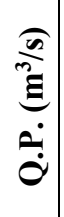 } & \multirow{2}{*}{ 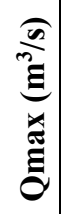 } & \multirow{2}{*}{ 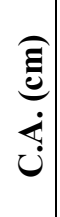 } & \multirow{2}{*}{ 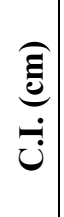 } & \multirow{2}{*}{ 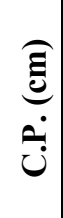 } & \multicolumn{6}{|c|}{$\begin{array}{l}\text { Q max with different } \\
\text { probabilities }\left(\mathrm{m}^{3 /} \mathbf{s}\right)\end{array}$} \\
\hline & & & & & & & & & & & $\overline{0}$ & $\stackrel{n}{0}$ & - & $\sim$ & in & \\
\hline \multirow{2}{*}{ } & 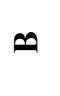 & $\Xi$ & $\begin{array}{l}n \\
\infty \\
n \\
\end{array}$ & $\begin{array}{c}n \\
\infty \\
\sim \\
\sim\end{array}$ & $\hat{\mathscr{\infty}}$ & $\bar{n}$ & $\begin{array}{l}\hat{\text { ते }} \\
\text { nat }\end{array}$ & 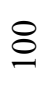 & $\stackrel{\circ}{n}$ & 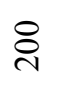 & 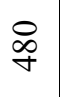 & 品 & 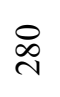 & సి & $\tilde{\Omega}$ & $\hat{\varrho}$ \\
\hline & u & $\stackrel{+}{\sigma}$ & $\stackrel{\ominus}{\Xi}$ & $\begin{array}{l}\infty \\
\infty\end{array}$ & $\begin{array}{l}\stackrel{\infty}{\infty} \\
\sim\end{array}$ & mे & $\stackrel{n}{\stackrel{0}{0}}$ & ஷृ & तె & ষ & ల్ల & \& & $\stackrel{\circ}{n}$ & $\stackrel{\mathcal{F}}{\forall}$ & $\hat{\curvearrowright}$ & $\stackrel{m}{\sim}$ \\
\hline
\end{tabular}

H.S.= hydrometric station; $\mathrm{B}=$ Bușteni; $\mathrm{C}=$ Câmpina $\mathrm{F}=$ river basin area; Hmed $=$ mean altitude of the river basin $(\mathrm{m})$; Q.A. = attention flow (m3/s);Q.I.= flood flow $\left(\mathrm{m}^{3} / \mathrm{s}\right) ; \mathrm{Q} . \mathrm{P} .=$ danger flow $\left(\mathrm{m}^{3} / \mathrm{s}\right)$; Qmax $=$ maximum flow $\left(\mathrm{m}^{3} / \mathrm{s}\right)$; C.A. $=$ attention level $(\mathrm{cm})$; C.I. $=$ flood level $(\mathrm{cm}) ;$ C.P. $=$ danger level $(\mathrm{cm})$.

Data source: INHGA database

\section{RESULTS}

Next, the annual and monthly maximum flows of the Prahova River at the two analyzed hydrometric stations are plotted as graph (Fig. 3 and Fig. 4), in order to observe the succession of years and months with rich flows.

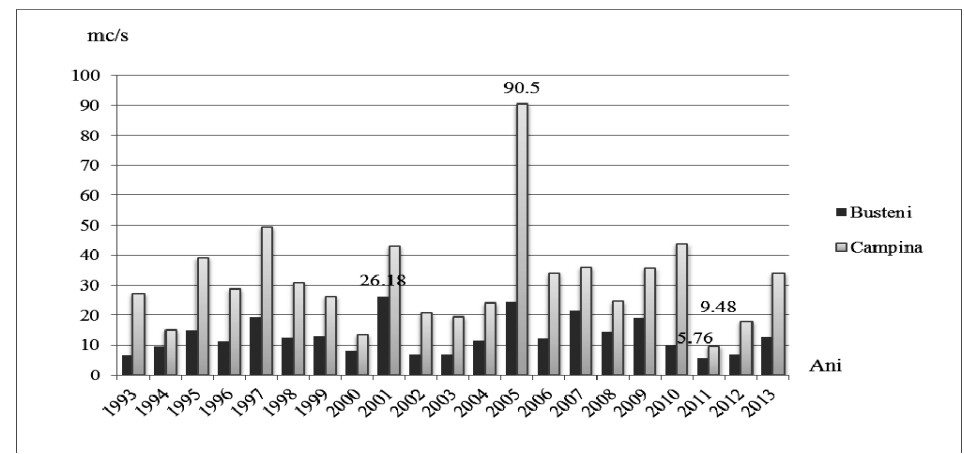

Fig. 3. Prahova River maximum annual flows at Bușteni H.S. and Câmpina H.S. (1993-2013) 


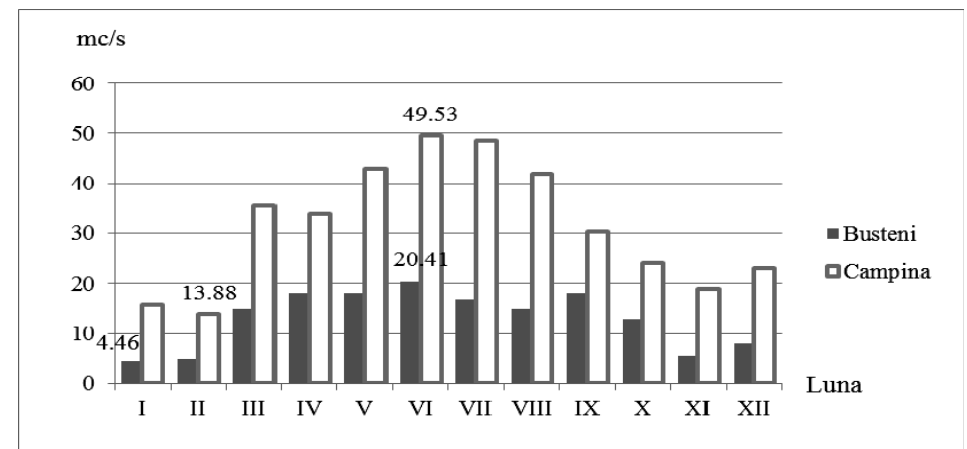

Fig. 4. Prahova River maximum monthly flows at Buşteni H.S. and Câmpina H.S. (1993-2013)

Hydrology International Dictionary defines "flood" as an increase, in a relatively short time, of the water level of an river to a peak, where the water level returns to a slower pace (WMO, 2011).

From the statistical analysis of the 42 annual floods recorded at Buşteni and Câmpina hydrometric stations, in the 1993-2013 period, in terms of distribution during the year, March is observed to have the highest number of floods, and at the seasonal level the dangerous phenomena of this kind manifesting itself primarily in spring (Table 2). Analyzing the yearly distribution of floods, we find that in most cases the cause of their occurrence are local precipitation with particularly high intensities in small hydrographic sub-basins, or generalized rainfall, but with intense and significant amounts of water. It can be observed that the floods occurred in the winter as well, due to the presence of the snow layer, over which precipitations fell and led to snow melting acceleration.

Table 2. The monthly and seasonal frequency of annual floods at Buşteni H.S. and Câmpina H.S. (1993-2013)

\begin{tabular}{|c|c|c|c|c|c|c|}
\hline Season & Month & $\begin{array}{c}\text { Bușteni } \\
\text { H.S. }\end{array}$ & $\begin{array}{c}\text { Câmpina } \\
\text { H.S. }\end{array}$ & $\begin{array}{c}\text { Total } \\
\text { monthly } \\
\text { floods }\end{array}$ & $\begin{array}{c}\text { Total } \\
\text { seasonal } \\
\text { floods }\end{array}$ & $\begin{array}{c}\text { Total } \\
\text { seasonal } \\
\text { floods (\%) }\end{array}$ \\
\hline \multirow{2}{*}{ Winter } & January & 1 & 2 & 3 & 3 & $7,14 \%$ \\
\hline \multirow{2}{*}{ Spring } & March & 6 & 4 & 10 & \multirow{2}{*}{27} & $64.3 \%$ \\
\cline { 2 - 5 } & April & 5 & 4 & 9 & & \\
\cline { 2 - 5 } & May & 3 & 5 & 8 & & \multirow{2}{*}{12} \\
\hline \multirow{2}{*}{ Summer } & June & 4 & 3 & 7 & & \\
\cline { 2 - 5 } & July & 2 & 3 & 5 & & \\
\hline
\end{tabular}

H.S. $=$ Hydrometric station

Data source: INHGA database

Table 3 shows the characteristic elements of the flood waves produced in the years 2001 and 2007. The graphs related to them are represented in the following 4 figures (Fig. 5, 6, 7 and 8). 
Table 3. Prahova River characteristic elements of flood waves, Buşteni and Câmpina H.S. (2001, 2007)

\begin{tabular}{|c|c|c|c|c|c|c|c|c|c|c|c|c|}
\hline \multirow[b]{2}{*}{$\dot{\ddot{x}}$} & \multirow[b]{2}{*}{$\underset{y}{\stackrel{x}{2}}$} & \multicolumn{11}{|c|}{$\begin{array}{l}\text { CHARACTERISTIC ELEMENTS OF FLOOD WAVES, PRAHOVA } \\
\text { RIVER }\end{array}$} \\
\hline & & $\stackrel{\text { an }}{\stackrel{a}{a}}$ & $\frac{\stackrel{n}{a}}{\stackrel{a}{a}}$ & 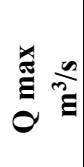 & 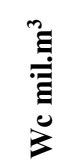 & 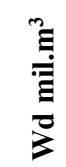 & 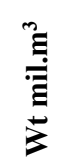 & $\begin{array}{l}\Xi \\
\Xi \\
\underline{\Xi} \\
\underline{\Xi}\end{array}$ & تٍُّ & 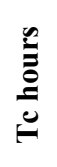 & 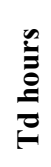 & $\stackrel{0}{E}$ \\
\hline B & \multirow{2}{*}{ હे } & 12,8 & 13,3 & 107 & 0,8 & 2,8 & 3,6 & 26 & 0,21 & 14 & 45 & 59 \\
\hline C & & 13,5 & 32.4 & 225 & 2,4 & 6,7 & 9,1 & 18,4 & 0,19 & 8 & 56 & 64 \\
\hline B & \multirow{2}{*}{ હે } & 9.4 & 19.6 & 102 & 1,6 & 3,2 & 4,8 & 33,9 & 0.4 & 18 & 20 & 38 \\
\hline C & & 27,9 & 31 & 250 & 3,6 & 5,7 & 9,3 & 18,9 & 0,36 & 10 & 22 & 32 \\
\hline
\end{tabular}

$\mathrm{B}=$ Bușteni; C=Câmpina; H.S. = Hydrometric station; $\mathrm{Qbi}=$ initial basic flow $\left(\mathrm{m}^{3} / \mathrm{s}\right)$; $\mathrm{Qbf}=$ final basic flow $\left(\mathrm{m}^{3} / \mathrm{s}\right) ; \mathrm{Q} \max =$ maximum flow $\left(\mathrm{m}^{3} / \mathrm{s}\right) ; \mathrm{Wc}=$ growth volume $\left(\mathrm{mil}^{\mathrm{m}} \mathrm{m}^{3}\right) ; \mathrm{Wd}=$ decrease volume $\left(\mathrm{mil}^{\mathrm{m}} \mathrm{m}^{3}\right) ; \mathrm{Wt}=$ total volume $\left(\right.$ mil. $\left.\mathrm{m}^{3}\right) ; \mathrm{Hs}=$ drained water layer $(\mathrm{mm})$; Coef. formă $=$ shape coefficient; $\mathrm{Tc}=$ grouth time (hours); $\mathrm{Td}=$ decrease time (hours); $\mathrm{Tt}=$ total time (hours);

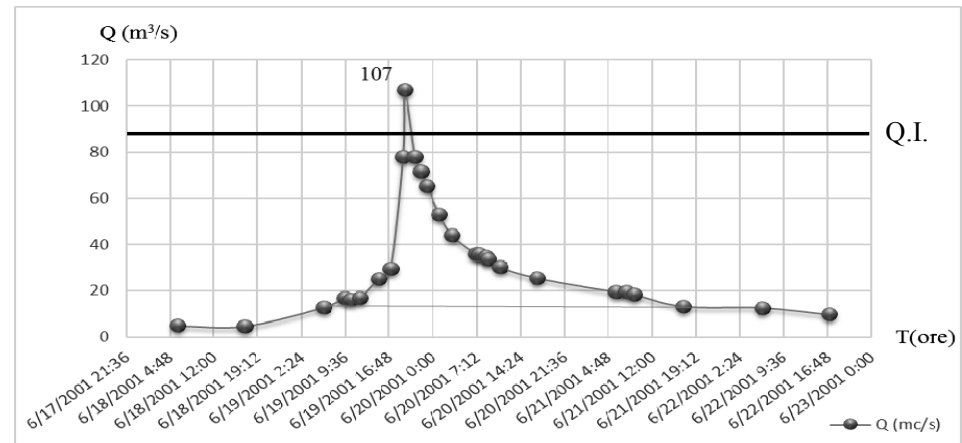

Fig. 5. The flood hydrograph of 18-22.VI.2001, Prahova River, Bușteni H.S.

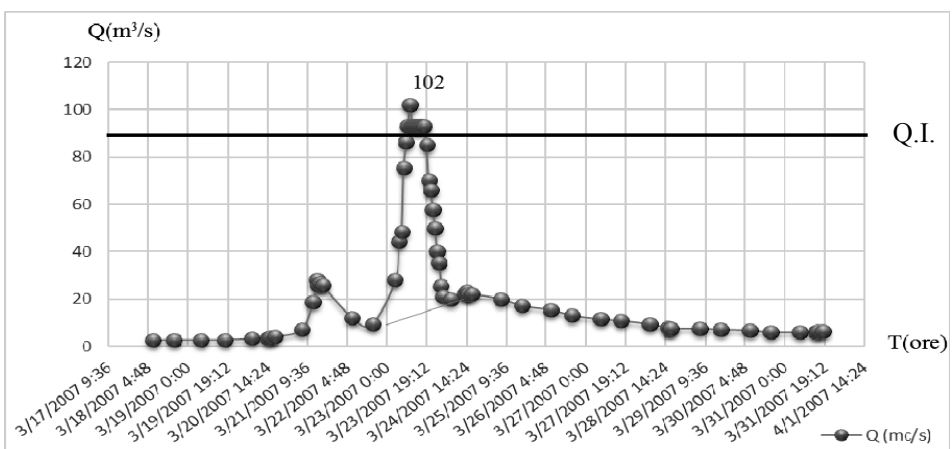

Fig. 6. The flood hydrograph of 18-31.III.2007, Prahova River, Bușteni H.S. 


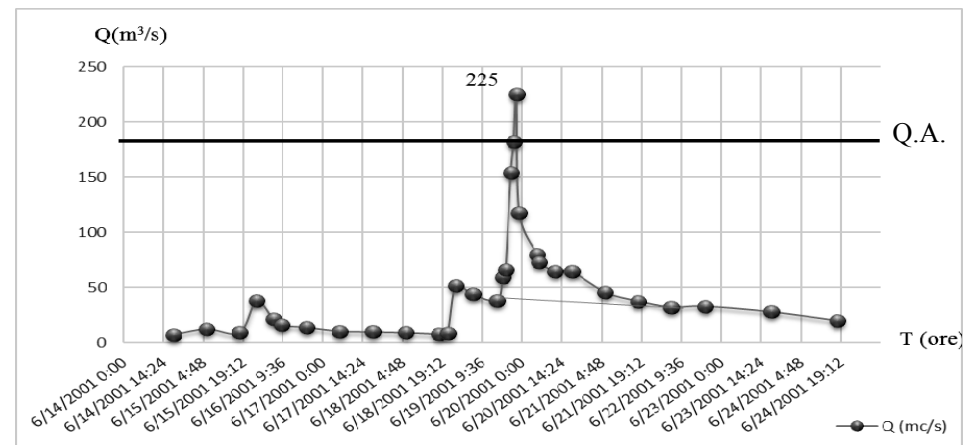

Fig. 7. The flood hydrograph of 14-24.VI.2001, Prahova River, Câmpina H.S.

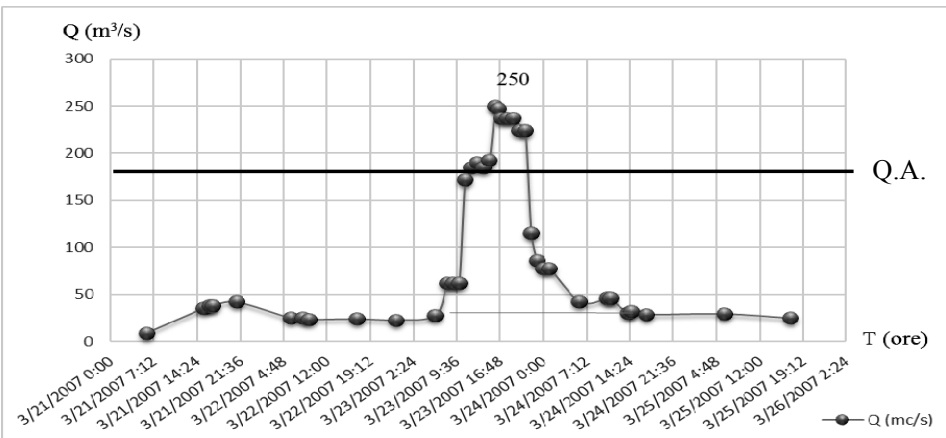

Fig. 8. The flood hydrograph of 21-25.III. Prahova River, Câmpina H.S.

\section{CONCLUSIONS}

Floods are dangerous hydrometeorological events, resulting from excess rainfall, being considered natural disasters, that affect society and the environment, causing direct or indirect economic damages (Stănescu, V., Drobot, R., 2002).

The maximum flow impact on society is primarily reflected in material assets, with the negative effect of even loss of life. During floods the infrastructure (buildings, roads, railways, bridges etc.) is affected, the soil - by washing, erosion and sliding, water - by contamination. Social and economic activities are also affected, as well as transport and telecommunications.

As previously shown, significant increases in flow rates on the upper and middle course of the Prahova River occurred mainly in spring and summer, the most affected years being 1997, 2001, 2005, 2007 and 2010.

Analyzing the maximum flows from the two hydrological stations (Buşteni H.S. and Câmpina H.S.), during the 1993-2013 period, it can be observed that the maximum flows from the Câmpina H.S. are superior than those from Buşteni H.S., due to the influence of the physico-geographic factors on the flow, and their location within the Prahova River basin.

In the following pictures (Photo 3 and Photo 4) are presented some examples of hydro-technical structures, designed to combat the negative effects of 
the maximum leakage on bridges, erosion control, bank protection, sewerage works of watercourses etc.

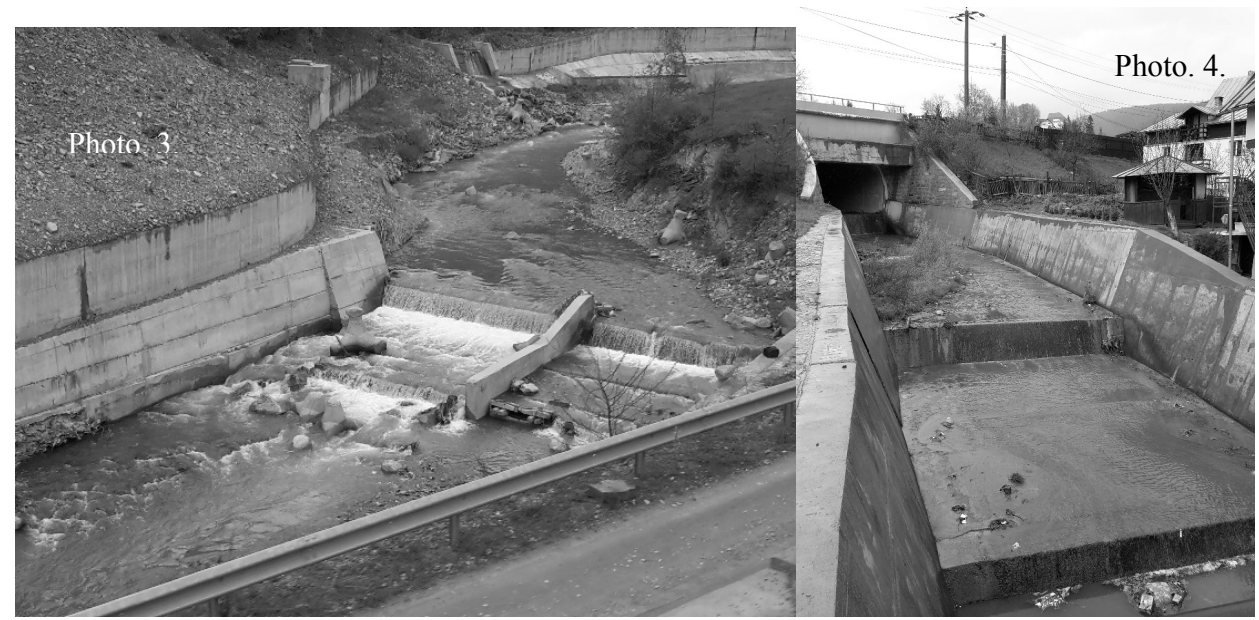

Photo. 3 \& 4. Facilities for diminishing the negative effects of floods on bridges, Prahova River, Comarnic. Sewerage work with concreting of the riverbed and with shore protection, Valea Cerbului River, Bușteni

\section{REFERENCES}

1. Musy, (2005), Cours Hydrologie générale. [ http://echo.epfl.ch/e-drologie/ ]

2. Nedelcu, A. (2010), Valea Prahovei și sistemul său fluviatili-Studiu de geografie fizică cu privire specială asupra hidrografiei, Ed. Univeristară, București

3. Pișota, I., Zaharia, L., Diaconu, D. (2005), Hidrologie, Ed. Univeristară, București

4. Roşu, Al. (1973), Geografia Fizică a României, Ed. Didactică şi Pedagogică, București

5. Stănescu, V., Dobrot, R. (2002), Măsuri nestructurale de gestiune a inundaţiilor, Ed. ${ }^{*} \mathrm{H}^{*} \mathrm{G} * \mathrm{~A}$, Bucuresti

6. *** WMO (2011), Manual on flood forecasting and warning

7. *** (1992) - Atlasul Cadastrului apelor din România 1, partea I - date morfohidrologice asupra rețelei hidrografice de suprafață, Ministerul Mediului Aqaproiect S.A, București

8. *** (1971) - Râurile României. Monografie hidrologică, IMH, București 